\title{
Graphics Development Control and Analysis Process Capability Based Distribution Beta Binomial
}

\author{
$1^{\text {st }}$ Hendro Permadi \\ FMIPA \\ Universitas Negeri Malang \\ Malang, Indonesia \\ hendro.permadi.fmipa@um.ac.id \\ $4^{\text {th }}$ Ira Nurmawati \\ FMIPA \\ Universitas Negeri Malang \\ Malang, Indonesia \\ iranurmawati04@gmail.com
}

\author{
$2^{\text {nd }}$ Eddy Budiono \\ FMIPA \\ Universitas Negeri Malang \\ Malang, Indonesia \\ eddy.budiono.fmipa@um.ac.id
}

\author{
$3^{\text {rd }}$ Susy Kuspambudhi \\ FMIPA \\ Universitas Negeri Malang \\ Malang, Indonesia \\ susy.kuspambudi.fmipa@um.ac.id
}

\begin{abstract}
The proportion of a product defect is usually considered to be fixed, so as to control the quality of a product defect proportions using $p$ control chart (based Binomial), but not necessarily the proportion of a product defect fixed (same), but having such distribution Beta distribution, it is often the case when in the production process of a product contained in the shift operator (no overdispersion). Thus the proportion of this product defects Beta Binomial distribution that arises when $\pi_{i}$ $=\pi$ wrong and $\pi_{\mathrm{i}}$ are assumed to have a beta distribution, namely: $\pi_{i} \sim$ beta $(a, b)$, for $a>0$ and $b>0$. The purpose of this paper is the result of fundamental research goal is to develop methods that control charts and process capability analysis based Beta Binomial distribution as an alternative to the process capability analysis based on the data distribution Binomial proportion Bremer star product defects. The results of the Beta Binomial control chart Bremer star appears that nothing is out of proportion with the control limit $U C L=0.053884$ and $L C L=$ 0.05064, while the individual control chart star chart $p$-Bremer also no defects proportion out with $\mathrm{UCL}=0.7393$ and $\mathrm{LCL}=0$ (less realistic or more in favor of the manufacturer). From the results of the control chart design Bremer star Beta Binomial appears that hose upper control limit and lower control limit is narrower (i.e tighter control chart) than the individual control chart of the p-chart, it is very beneficial for consumers. Based on the analysis capabilities Binomial distribution processes have defective 5.51 percent with the lower limit 5,49 and upper limit 5.52. While the value of 55082 PPM defective in one million products means there are approximately $\mathbf{5 5 0 8 2}$ non-conforming products, with a lower limit of 54938 and a ceiling of 55227 products. While the results of the analysis Beta Binomial distribution has a defective $\mathbf{5 . 2 3}$ percent with a lower limit of 5.21 and an upper limit of 5.24. While the value of 52264 PPM defective in one million products means there are approximately 52264 non-conforming products, with a lower limit of 52123 and a ceiling of 52405 products. These results indicate that the process capability analysis Beta Binomial distribution has a smaller value of percent defective with a narrower interval compared with the results of the analysis of the ability of the binomial distribution, this will benefit the producers and consumers (the hose tighter).
\end{abstract}

Keywords- Binomial, Beta Binomial Distribution, Control Charts, Process Capability Analysis

\section{INTRODUCTION}

The use of the binomial distribution opportunities for these individuals would be appropriate if the number of binary observations can make the proportion of observations become an independent and equal value. But sometimes individual binary observations have values different proportions in the same individual in the other group. The number of events 'success' can only be assumed to have a binomial distribution when the binary components are independent observations. Lack of freedom between binary observations will lead to a greater variety than the variance on the binomial distribution. Great Variety is an indication of a problem overdispersion in the observations of binary data.

The emergence of overdispersion problem in binary data observations can be explained by two things: the variability in response to opportunities and the correlation between the response variables. Both of these events are events that reciprocal, meaning that if there are variations in the response opportunities, then there is a correlation between the response variables. If there is a positive correlation between observations, then the value of the parameter estimators of the distribution does not provide a correlation that may have underestimated the raw error. Mc Cullagh and Nelder stated that the two events can occur because of grouping (clustering) in the population [1]. While Collet mentions that the events that arise due to a number of experimental units were observed several times under the same conditions, so it will obtain a different response opportunity from one experiment to another experiment [2].

As a result of problems in the binary data overdispersion caused by the variability in the response opportunities as well as the correlation between the response variable is the value estimator variance of the binomial distribution is used [3]. One alternative solution by using the Beta Binomial distribution approaches in each group [4].

On the other hand, in statistical quality control for data attributes to assume Binomial used to demonstrate the characteristics of quality in accordance with the specification 
or not in accordance with the specifications. There are two groups of statistical quality control charts for attribute data that is based on the binomial distribution as $p$-charts and $n p$ chart.

The use of control charts p-charts and np-chart is used to determine the proportion of defective products and the number of defective products. The proportion of faults (defects) in a product is generally not the same even though the samples were taken the same (constant), especially the samples taken are not constant. During this center line graph p-chart using the concept of the average value of proportions, whereas Beta Binomial Distribution alternatives can be used as an alternative Binomial because more subtle predicted values so that consumers and producers of their rights can be protected.

\section{METHODS}

\section{Data Source}

The data in this paper is the result of fundamental research Fiscal Year 2013/2014 taken from the beverage company PT. Multibintang Indonesia Tbk, where the production process using three shifts to employees' work time, the data taken in the form of measurement data whether or not a product defect. Bremer star data used in the form of data Disability Save Bremer production per day the period of January 1, 2008 - 28 April 2008, during the 87 days.

\section{Data analyses}

The method of analysis used in this paper refers to the fundamental research first year (2013) and the second year (2014), the steps are arranged as follows:

1. Examine the proportion of three shifts with proportion test.

2. Specifies the maximum likelihood function Beta Binomial distribution to determine the size of the concentration and size distribution

3. Binomial distribution detection of the data samples

4. Detection Beta distribution to the distribution of the proportion of the data.

5. Determining Structure Distribution Multiplication of two distributions, the binomial distribution, and the distribution betabinomial.

6. Designing programs binomial distribution with beta binomial distribution by making doodles with WinBugs software.

7. Perform parameter estimation Beta binomial with Markov Chain Monte Carlo (MCMC) with iteration.

8. Pitted two distributions to test the hypothesis of two binomial distribution and Beta Binomial distribution with Bayes factor criteria.

9. Designing, analyzing and comparing the graphics controller the Beta Binomial and p-Chart for the data variable proportion Bremer Star
10. Designing, analyzing and comparing the Process Capability Analysis based Binomial and Beta Binomial distribution for a variable proportion of data Bremer Star

\section{RESULTS AND DISCUSSION}

Based on data from the proportion of disability Bremer Star on three shifts given value data description in Table 1 as follows:

Table 1. Proportion description / data Disability Bremer Star Products

\begin{tabular}{|c|c|c|c|c|c|}
\hline \multicolumn{2}{|c|}{$\begin{array}{c}\text { Average Total } \\
\text { Product }\end{array}$} & $\begin{array}{c}\text { Average } \\
\text { Total }\end{array}$ & \multicolumn{2}{c|}{$\begin{array}{c}\text { On Average } \\
\text { Disabilities }\end{array}$} & $\begin{array}{c}\text { Average } \\
\text { Total }\end{array}$ \\
\hline Shift 1 & 179375 & 187309 & Shift 1 & 10532 & \multirow{2}{*}{10317} \\
\cline { 1 - 1 } Shift 2 & 214715 & & Shift 2 & 12583 & \\
\cline { 1 - 1 } Shift 3 & 167836 & & Shift 3 & 7837 & \\
\hline
\end{tabular}

Based on the proportion of disability in the star test Bremer between shifts, shift assay results first and third shift, and shift 2 and 3 are very significant shift (no difference), while the test results shift 1 and 2 did not shift significantly. This shows that the proportion of disability in between shifts Bremer star is not the same, for it is necessary to detect the distribution of the proportion of the defects in three shifts. Detection results on the distribution of the weekly proportion shift 1, 2, 3 Easy fit software with results obtained the distribution of the selected alternative is the Beta distribution.

Table 2. Distribution Detection Proportion Bremer Star

\begin{tabular}{|c|c|c|c|c|c|c|c|}
\hline \multicolumn{8}{|c|}{ Goodness of Fit - Summary } \\
\hline \multirow[t]{2}{*}{$=$} & \multirow[t]{2}{*}{ Distribution } & \multicolumn{2}{|c|}{$\begin{array}{l}\text { Kolmogorov } \\
\text { Smimov }\end{array}$} & \multicolumn{2}{|c|}{$\begin{array}{c}\text { Anderson } \\
\text { Darling }\end{array}$} & \multicolumn{2}{|c|}{ Chi-Squared } \\
\hline & & Statistic & Rank & Statistic & Rank & Statistic & Rank \\
\hline 1 & Beta & 0,08741 & 6 & 0,52848 & 8 & 1,7514 & 5 \\
\hline 2 & Burr & 0,11488 & 25 & 0,91106 & 21 & 4,3498 & 20 \\
\hline 3 & Burr $(4 P)$ & 0,08996 & 9 & 0,50255 & 7 & 2,9833 & 12 \\
\hline 4 & Cauchy & 0,13022 & 28 & 1,3799 & 27 & 3,3268 & 14 \\
\hline 5 & Dagum & 0,09906 & 8 & 0,30004 & 2 & 1,0733 & 3 \\
\hline 6 & Dagum (4P) & 0,08802 & 7 & 0,29924 & 1 & 1,0722 & 2 \\
\hline 7 & Ertang & 0,16339 & 39 & 2,1831 & 34 & 8,2687 & 28 \\
\hline 8 & Ertang (3P) & 0,09437 & 15 & 0,70774 & 17 & 3,6871 & 16 \\
\hline 9 & Error & 0,08477 & 4 & 0,49492 & 5 & 2,3117 & 7 \\
\hline 10 & Error Function & 0,71547 & 56 & 125,32 & 56 & 338,16 & 51 \\
\hline
\end{tabular}

The distribution of the selected alternative is the beta distribution and the value obtained from the parameter Beta distribution [5] as shown in Fig. 1. as big as

$\alpha_{1}=3,594 ; \alpha_{1}$ adalah parameter bentuk , $\alpha_{1}>0$

$\alpha_{2}=3,594 ; \alpha_{2}$ adalah parameter bentuk, $\alpha_{2}>0$ 


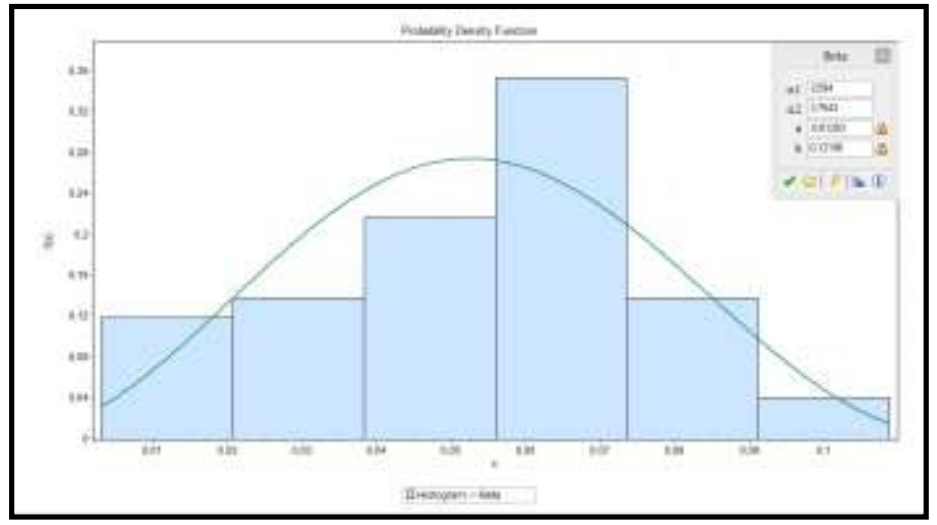

Fig. 1. Figure detection results Bremer star beta distribution

Based on data from product defects Stars Bremer, then made individual control chart (p-chart) of the binomial distribution is given in Fig. 2 as follows [6]:

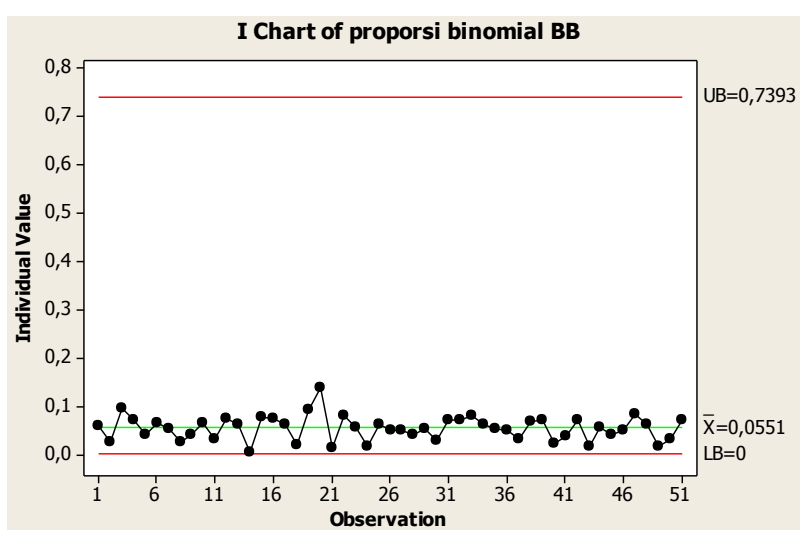

Fig. 2. Proportion Disability Graphics Controller Bremer Star (BB)

While based on the Beta parameters obtained, then made the Beta Binomial control chart is given in Fig.3. The results of the Beta Binomial control chart for Bremer Star disability appears that nothing is out of proportion with the control limit UCL and LCL $=0.053884=0.05064$, for Bremer Star, as well as when using the Binomial Individual control chart no defect proportion coming out with $\mathrm{UCL}=0.7393$ and $\mathrm{LCL}=$ 0 (less realistic or more in favor of the manufacturer).

From the results of the control chart design Bremer star Beta Binomial appears that hose upper control limit and lower control limit is narrower (i.e. tighter control chart) than the individual control chart of the p-chart, it is very beneficial for consumers.

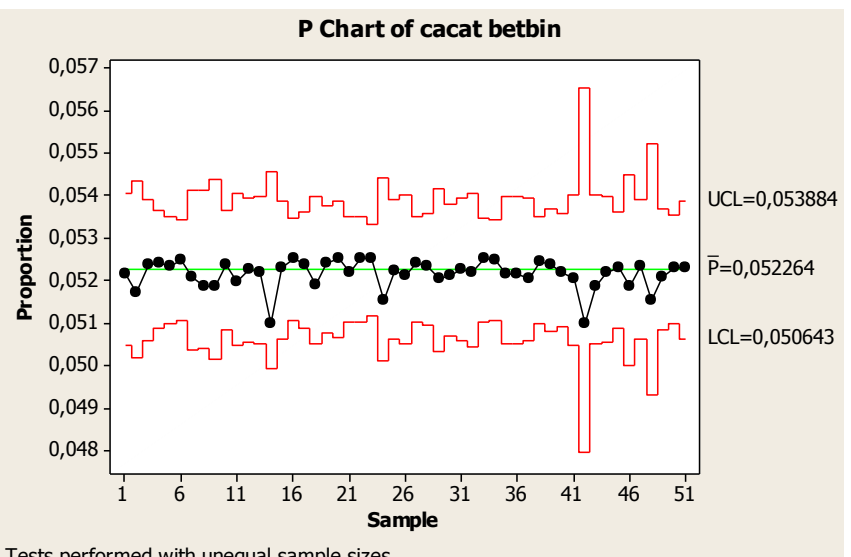

Fig. 3. Graph Control Beta Binomial Proportion Bremer star Disability

Table 3. Results of MCMC iterations defect proportion Bremer Star

\begin{tabular}{|c|c|c|c|c|c|c|c|c|}
\hline node & mean & sd & MC error & $\mathbf{2 . 5 \%}$ & Median & 97.5\% & start & sample \\
\hline alpha1 & 120.9 & 295.3 & 15.6 & 0.06439 & 10.82 & 998.6 & 501 & 99500 \\
\hline beta1 & 2919.0 & 7415.0 & 384.8 & 0.3119 & 234.4 & 26550 & 501 & 99500 \\
\hline P[1] & 0.5003 & 0.2241 & $7.38 \mathrm{E}-4$ & 0.09394 & 0.5003 & 0.9073 & 501 & 99500 \\
\hline P[2] & 0.4997 & 0.2241 & $7.38 \mathrm{E}-4$ & 0.09274 & 0.4997 & 0.9061 & 501 & 99500 \\
\hline
\end{tabular}

The number $\lambda^{(\mathrm{g})}>0.5$ is obtained from $\mathrm{N}$-iteration

$$
\begin{aligned}
\mathbf{B} \mathbf{f}_{12} & =\frac{\text { The number } \lambda^{(\mathrm{g})}<0.5 \text { was obtained from } N \text {-iteration }}{\mathbf{0 , 4 0 0 3}}=\mathbf{1}, \mathbf{0 0 1}
\end{aligned}
$$

Table 4. Interpretation Value Bayes Factor in Selection Hypothesis

\begin{tabular}{|c|c|c|}
\hline $\log 10\left(\mathbf{B f}_{\mathbf{1 2}}\right)$ & $\mathbf{B f}_{\mathbf{1 2}}$ & Evidence reliability $\mathbf{H}_{\mathbf{1}}$ of $\mathbf{H}_{\mathbf{2}}$ on the data \\
\hline $0-0.5$ & $1-3.2$ & Nothing \\
\hline $0.5-1$ & $3.2-10$ & Strong Enough \\
\hline $1-2$ & $10-100$ & Strong \\
\hline$>2$ & $>100$ & Very Strong \\
\hline $\log 10\left(\mathbf{B f}_{\mathbf{1 2}}\right)$ & $\mathbf{B f}_{\mathbf{1 2}}$ & Evidence reliability $\mathbf{H}_{\mathbf{1}}$ of $\mathbf{H}_{\mathbf{2}}$ on the data \\
\hline
\end{tabular}




\begin{tabular}{|c|c|c|}
\hline $0-0.5$ & $1-3.2$ & Nothing \\
\hline $0.5-1$ & $3.2-10$ & Strong Enough \\
\hline $1-2$ & $10-100$ & Strong \\
\hline$>2$ & $>100$ & Very Strong \\
\hline
\end{tabular}

Tests Binomial distribution proportion Bremer Star defects using multiplication structure distribution [7,8]. the method of Markov Chain Monte Carlo (MCMC) with software tools WinBug using 100,000 iterations times obtained results as shown in Table $3[9,10]$. Bayes factors and criteria, the value of Bayes factor of 1.001 [11].

The results obtained 1,001 Bayes factor in Bremer Star variables when compared with the criteria table Bayes factor is between 1 to 3.2 , it can be said that there is no reliability

at the is equal to the binomial distribution Beta $[12,13]$. Thus the beta binomial distribution can be used to replace the binomial distribution, or in other words the control chart Beta binomial proportion Bremer Star defect can be used as an alternative to the proportion of defective control chart (p-Chart). Based on these results, the next steps are needed to determine whether the production process in accordance with the specifications set forth by the company using process capability analysis based Beta Binomial distribution [14].

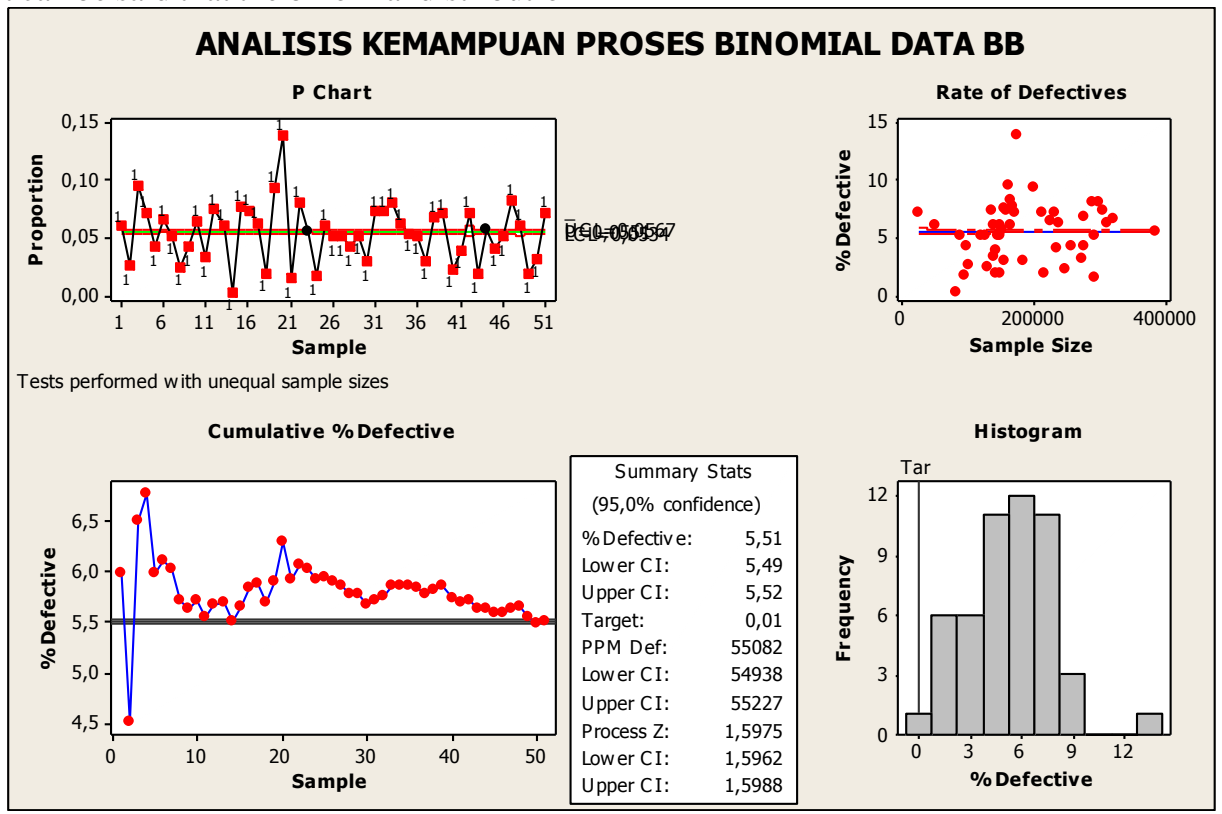

Fig. 4. Graph Star Disability Process Capability Analysis Bremer (BB)

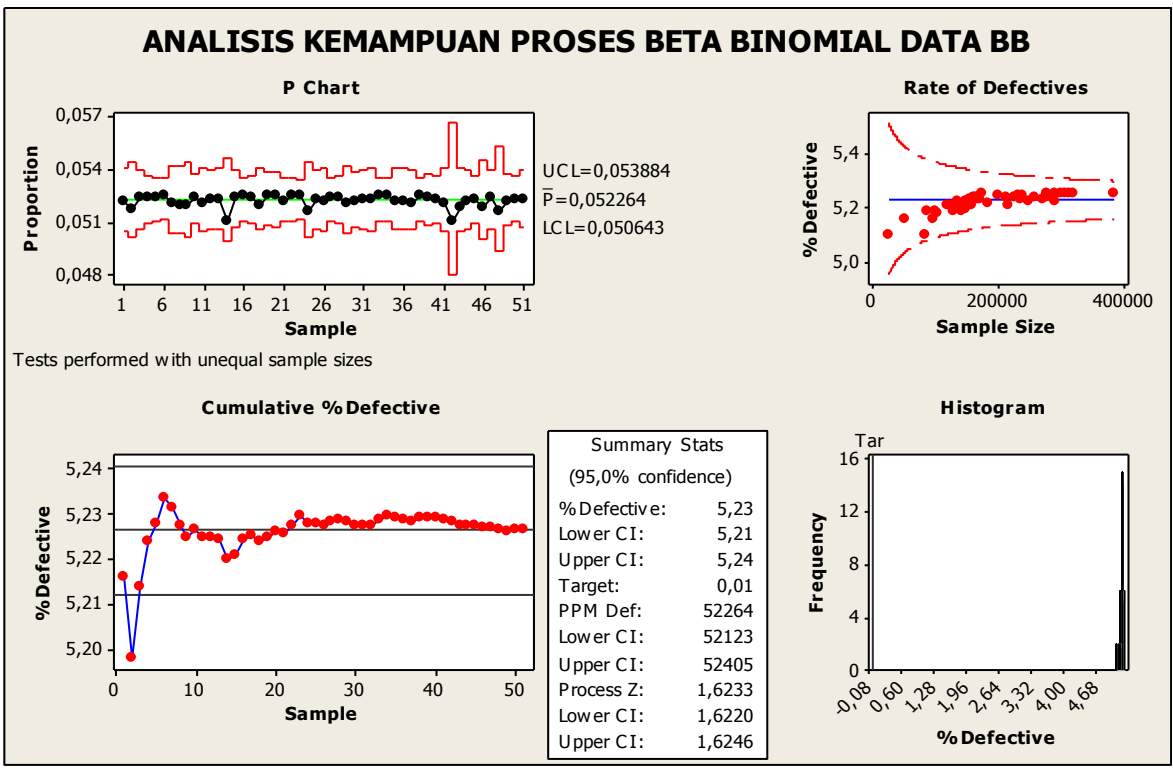

Fig. 5. Graph Beta Process Capability Analysis Binomial Proportion Disability Bremer star 
Based on the results of the Binomial distribution process capability analysis (Fig.4) it appears that the process capability analysis Binomial distribution has a defective 5.51 percent with the lower limit and upper limit of 5.495 .52 . While the value of $55082 \mathrm{ppm}$ defective in one million product means there are approximately 55082 non-conforming products, with a lower limit of 54938 and a ceiling of 55227 products.

As for the graphics process capability analysis for the Beta Binomial proportion Bremer Star disability are given in Fig. 5. The results of the analysis of the ability of the Beta Binomial distribution process, it appears that the process capability analysis Beta Binomial distribution has a defective 5.23 percent with a lower limit of 5.21 and upper limit 5.24. While the value of 52264 ppm defective in one million product means there are approximately 52264 non-conforming products, with a lower limit of 52123 and a ceiling of 52405 products.

These results indicate that the process capability analysis Beta Binomial distribution has a smaller value of percent defective with a narrower interval compared with the results of the analysis of the ability of the binomial distribution, this will benefit the producers and consumers (the hose tighter).

\section{CONCLUSION}

The results of the Beta Binomial control chart Bremer star appears that nothing is out of proportion with the control limit $\mathrm{UCL}=0.053884$ and $\mathrm{LCL}=0.05064$, while the individual control chart star chart p-Bremer also no defects proportion out with UCL $=0.7393$ and $\mathrm{LCL}=0$ (less realistic or more in favor of the manufacturer). From the results of the control chart design Bremer star Beta Binomial appears that hose upper control limit and lower control limit is narrower (i.e tighter control chart) than the individual control chart of the p-chart, it is very beneficial for consumers.

The results obtained Bayes factor 1.001, compared with the criteria table Bayes factor is between 1 to 3.2 , it can be said that there is no reliability on or it can be said that the binomial distribution is equal to the Beta Binomial distribution well, thus Beta Binomial distribution can be used to replace the Binomial distribution (control chart Beta Binomial proportion Bremer Star defect can be used as an alternative to the proportion of defective control chart p-Chart).

Based on the analysis capabilities Binomial distribution processes have defective 5.51 percent with the lower limit of 5.49 and the upper limit of 5.52. While the value of 55082 ppm defective in one million product means there are approximately 55082 non-conforming products, with a lower limit of 54938 and a ceiling of 55227 products. While the results of the analysis of the ability of the Beta Binomial distribution has a defective 5.23 percent with a lower limit of 5.21 and a upper limit of 5.24. While the value of 52264 ppm defective in one million product means there are approximately 52264 non-conforming products, with a lower limit of 52123 and a ceiling of 52405 products.

These results indicate that the process capability analysis Beta Binomial distribution has a smaller value of percent defective with a narrower interval compared with the results of the analysis of the ability of the binomial distribution.

\section{REFERENCES}

[1] Mc Cullagh, P., and J.A. Nelder, Generalized Linier Model. $2^{\text {nd }}$ Ed., New York Chapman and Hall, 1983.

[2] Collet, D., Modeling Binary Data, London : Chapman and Hall, 1990

[3] Gange, S.J. and Munoz, A., "Use of the Beta-Binomial Distribution to Model Effect of policy Change on Appropriatness of Hospital Stays", Applied Statistics, vol. 45, pp. 371-382, 1996.

[4] Grifiths, D.A., "Maximum Likelihood Estimation for the Beta-Binomial Distribution ang An Aplication to the Household Distribution of the total Number of Cases of A Disease", Biometrics, vol. 29, pp. 637-648, 1973.

[5] Carota, C., Parmigiani, G. and Polson, N.G., "Diagnostic measures for model Critism", Journal of the American Statistical Association, vol. 91(434), pp. 753-762, 1996.

[6] Permadi, H., "Pengembangan grafik Pengendali berbasis distribusi Beta Binomial. Penelitian fundamental", Proceding seminar KNPM V. 27 Juni MIPA UM. Malang, 2013.

[7] Permadi H. et al., "Kajian Regresi Binary Logistik dan Regresi Betabinomial Terhadap Kelulusan Suatu Mata Kuliah Penelitian Dosen Muda", 2003, unpublished.

[8] Permadi, H. Abadyo, Rahardjo, S., "Implementasi Struktur Perkalian Distribusi terhadap Pendeteksian Distribusi Campuran Poison : suatu kajian pada grafik u-chart dan analisis kemampuan proses, 2006, unpublished.

[9] Casella, G. and R.L. George, "Explaining Gibbs Sampler", Journal of the American Statistical Association, vol. 46(3), pp. 167-174, 1992.

[10] Gelman, A. Carlin J.B. and Stern, N.S., Bayesian Data Analysis, London, Chapman \& Hall, 1995.

[11] Kass, R.E. dan Raftery, A.E., "Bayes Factors", Journal of the American Statistical Assosiasion, vol. 90(430), pp. 773795, 1996.

[12] Permadi, H., "Pendeteksian Distribusi Campuran Weibull pada Analisis Kemampuan Proses Suatu Pendekatan dengan Markov Chain Monte Carlo.”, Jurnal Forum, Lembaga Penelitian Universitas Negeri Malang, 1995.

[13] Permadi, H. Abadyo, Parta, I.N., "Perbandingan Distribusi Binomial dan Distribusi Beta Binomial Menggunakan Struktur Perkalian Distribusi pada Analisis Kelulusan Mahasiswa Jurusan Matematika FMIPA UM, 2002, unpublished.

[14] Permadi, H., "Pengembangan Grafik Pengendali Distribusi Beta Binomial sebagai Penggant p-Chart Melalui MCMC", Proceding seminar KNM 17, MIPA ITS, Surabaya 23 Juli 2014. 